M. G. Ivanov, A. V. Nechaev, V. S. Mokrushin, O. I. Ostroukhova

Institute of fundamental education, Institute of chemical technology, Mira 28, 620002, Ekaterinburg. Phone: (343) 375-45-68. E-mail:a.v.nechaev@urfu.ru

\title{
The effect of fluorine-containing inhibitors of corrosion of copper in atmospheric conditions
}

The effect of fluorine-containing inhibitors of corrosion of copper in atmospheric conditions was studied by method of removing anodic polarization curves and corrosion of full-scale tests. The introduction of the inhibiting compositions as corrosion inhibitor of copper polyfluorinated amines leads to a decrease of the peak current of active dissolution of copper, which increases the corrosion resistance of copper wire rod during transportation in various climate conditions.

Key words: polarization curves, polyfluorinated amines, copper wire rods, corrosion inhibitor.

(C) Ivanov M. G., Nechaev A. V., Mokrushin V. S., Ostroukhova O. I., 2016

\section{Introduction}

The various amines are the effective corrosion inhibitors of copper in aggressive media. The inhibitory effect of some derivatives of triazole is caused by their adsorption and formation of the in- soluble complex of copper on the copper surface $[1,2]$. Therefore, the use of amines in the composition of the inhibiting composition can provide the protection from corrosion of copper rod for transportation.

\section{Experimental part}

The paper studies the anodic behavior of copper deposited on its surface preservative coating the inhibitory composition, containing polyfluorinated amine amine polyferrocenylsilane: $\mathrm{HCF}_{2}-\mathrm{CF}_{2}-$ $\mathrm{CF}_{2}-\mathrm{CF}_{2}-\mathrm{O}-\mathrm{CH}_{2}-\mathrm{CH}_{2}-\mathrm{NH}_{2}$, which was synthesized at the Department of technology of organic synthesis, Chemical technology Institute, Urals Federal University.
For accelerated evaluation of the protective action of inhibiting compositions and optimization of the composition of the preservative coating was used the method of removing anodic polarization curves. The polarization curves were recorded on a potentiostat-galvanostat IPC-PRO in potentiometric mode at a linear scan rate of potential of $2 \mathrm{mV} / \mathrm{s}$ in a three-electrode glass cell with sepa- 
rated anode and cathode spaces in $0.5 \mathrm{M}$ $\mathrm{NaCl}$ solution at $25^{\circ} \mathrm{C}$. The silver chloride electrode was served as the reference electrode in a saturated solution of potassium chloride. The potentials were calculated on present n.v.sh. The platinum sheet was served as the auxiliary electrode.

As object of study was used copper brand M00k ( $99.99 \%$ pure) for the manufacture of copper wire rod. To remove the polarization curves were used cylindrical rods of copper by diameter $8 \mathrm{~mm}$ with a total working area of $4 \mathrm{~cm}^{2}$. The field corrosion tests were conducted on samples of copper rod of length $150 \mathrm{~mm}$ and diameter $8 \mathrm{~mm}$ in the salt spray chamber Ascott 120 Plus.

The protective constitutions of inhibiting compositions were applied on a degreased with acetone, the working surface of the copper electrodes by dipping them in the solutions of inhibiting compositions for 15 seconds.

\section{Results and discussion}

The studies have shown that in the absence of inhibiting on the metal surface films anodic polarization curve for copper has the form characteristic of soluble active metal, followed by passivation. When potentials are of about $0.18-0.19$ changing to the passive state starts in copper electrode starts.

The polarization curves for copper, pre-treated in solutions of isopropanol with different content of polyfluorinated amine (PFA) are presented in the below figure.

As can be seen from Fig. when applied to a metal surface of the copper protective film from solutions containing the PFA, there was a significant decrease of peak current of active dissolution of copper on the polarization curve, indicating a slowing of the rate of anodic dissolution of copper and the inhibition of anodic reaction. From these data it follows that the magnitude of the limiting current of anodic dissolution of copper depends on the concentration of the PFA. The maximum anodic current density observed on polarization curves decreases with increasing concentrations of PFA and reaches a minimum value of $3.32 \%$ solution of inhibit- ing compositions on the basis of the PFA, which may indicate the increased corrosion resistance of copper is inhibited.

However, only the character of the polarization curves does not allow us to judge the influence of inhibitor on the corrosion resistance of copper in atmospheric conditions. So in addition to the electrochemical measurements were conducted in situ corrosion testing of samples of copper wire rod in the salt spray chamber Ascott 120 Plus.

The results of electrochemical measurements are consistent with the data

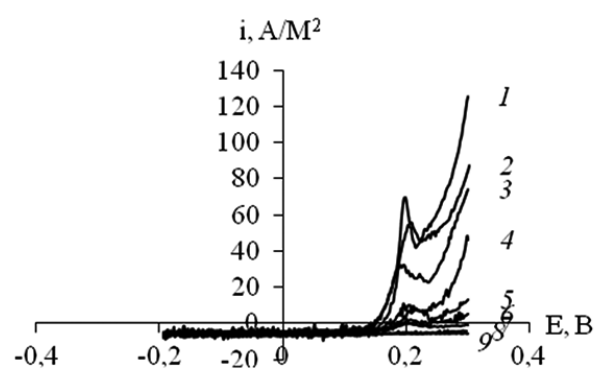

Fig. The polarization curves for copper, inhibiting composition treated with different concentration of PFA in isopropanol, $0.5 \mathrm{M}$ sodium chloride solution: 1 - pure copper; $2-0 \%$ the PFA; $3-0,25 \%$ PFA; $4-0.5 \%$ and the PFA; 5 - 0,75 \% PFA; 6 - $1 \%$ PFA; 7 - 1.25\% of the PFA; $8-1,66 \%$ PFA; $9-3,32 \%$ PFA 
of corrosion tests. The corrosion tests showed that pockets of corrosion on the copper samples without inhibiting compositions and treated with clean isopropanol appear already in the first days of exposure of samples in the chamber. At the same time on the samples treated in an anhydrous solution of inhibiting compositions on the basis of the PFA, corrosion lesions appear in 2-4 days depending on the concentration of the PFA. Of in- vestigated compounds inhibiting compositions the best results (up to 4 days) were achieved for $3,32 \%$ solution of inhibiting compositions on the basis of the PFA.

Thus, when used in inhibiting compositions as corrosion inhibitor of copper polyfluorinated amines can increase the corrosion resistance of copper wire rod during transportation in extreme conditions.

1. Tsygankova L. E., Rumiantsev A. F. The effect of oil coating and anionic composition of electrolyte on the corrosion inhibition of copper by benzotriazole in acidic media Corrosion: materials, protection. 2006;12:31-36.

2. Kuznetsov Y. I., Agafonkin M. O., Shikhaliev H. S., Andreeva N. P., Potapov A. Y. Adsorption and passivation of copper by triazoles in neutral aqueous solutions Corrosion: materials, protection. 2014;7:33-39. 


\section{М. Г. Иванов, А. В. Нечаев, В. С. Мокрушин, О. И. Остроухова Институт фундаментального образования, Химико-технологический институт, 620002, Екатеринбург, ул. Мира, 28 \\ Тел.: (343) 375-45-68 \\ E-mail:a.v.nechaev@urfu.ru}

\section{Влияние фторсодержацих ингибиторов на коррозию меди в атмосферных условиях}

Методом снятия анодных поляризационных кривых и натурных коррозионных испытаний изучено влияние фторсодержащих ингибиторов на коррозию меди в атмосферных условиях. Введение в состав ингибирующих композиций в качестве замедлителя коррозии меди полифторированных аминов приводит к снижению максимума тока активного растворения меди, что повышает коррозионную стойкость медной катанки при ее транспортировке в различных климатических условиях.

\footnotetext{
Ключевые слова: поляризационные кривые, полифторированные амины, медная катанка, замедлитель коррозии.

(C) Иванов М. Г., Нечаев А. В., Мокрушин В. С., Остроухова О. И., 2016
}

\section{Введение}

Различные амины являются эффективными ингибиторами коррозии меди в агрессивных средах. Тормозящее действие производных ряда триазола обусловливается их адсорбцией и образованием на поверхности

\section{Экспериментальная часть}

В работе изучено анодное поведение меди с нанесенным на ее поверхность консервационным покрытием ингибирующей композицией, содержащей в своем составе полифторированный амин - полифторалкилметиленоксиэтилен амина: $\mathrm{HCF}_{2}$ $\mathrm{CF}_{2}-\mathrm{CF}_{2}-\mathrm{CF}_{2}-\mathrm{O}-\mathrm{CH}_{2}-\mathrm{CH}_{2}-\mathrm{NH}_{2}$, который меди нерастворимого комплекса меди $[1,2]$. Поэтому использование аминов в составе ингибирующей композиции может обеспечить защиту от коррозии медной катанки при ее транспортировке.

был синтезирован на кафедре технологии органического синтеза Химикотехнологического института Уральского федерального университета.

Для ускоренной оценки защитного действия ингибирующих композиций и оптимизации состава консервационного покрытия использовался ме- 
тод снятия анодных поляризационных кривых. Поляризационные кривые снимались на потенциостате-гальваностате IPC-PRO в потенциодинамическом режиме при линейной развертке потенциала $2 \mathrm{mB} / \mathrm{c}$ в трехэлектродной стеклянной ячейке с разделенным анодным и катодным пространствами в 0,5 M растворе $\mathrm{NaCl}$ при температуре $25^{\circ} \mathrm{C}$. Электродом сравнения служил хлорсеребряный электрод в насыщенном растворе хлорида калия. Потенциалы пересчитаны на н.в.ш. Вспомогательным электродом служила листовая платина.

В качестве объектов исследования использовалась медь марки М00к
(99,99 \% чистоты), идущая на изготовление медной катанки. Для снятия поляризационных кривых использовались цилиндрические стержни из медной катанки диаметром 8 мм с суммарной рабочей площадью 4 см$^{2}$. Натурные коррозионные испытания проводились на образцах из медной катанки длиной 150 мм и диаметром 8 мм в камере солевого тумана Ascott 120 Plus.

Защитные составы ингибирующих композиций наносились на обезжиренную ацетоном рабочую поверхность медных электродов путем окунания их в растворы ингибирующих композиций в течение 15 c.

\section{Результаты и их обсуждение}

Исследования показали, что в отсутствие на поверхности металла ингибирующих пленок анодная поляризационная кривая для меди имеет вид, характерный для активно растворяющегося металла с последующей пассивацией. При потенциалах около

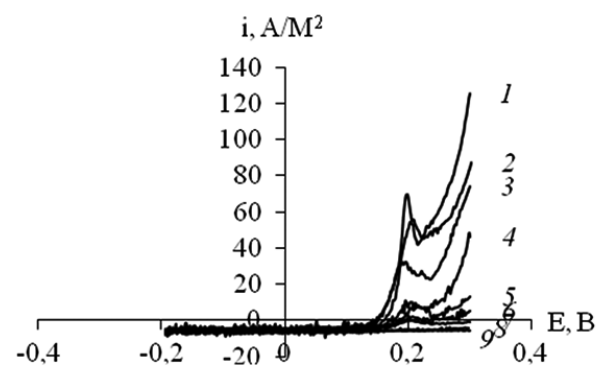

Рис. Поляризационные кривые для меди, обработанной ингибирующей композицией с различной концентрацией ПФА в изопропаноле, в 0,5 М растворе хлорида натрия: 1 - чистая медь; 2 - $0 \%$ ПФА; 3 - 0,25 \% ПФА; 4 - 0,5 \% ПФА; 5 0,75 \% ПФА; 6 - 1 \% ПФА; 7 - 1,25 \% ПФА; 8 - 1,66 \% ПФА; 9 - 3,32 \% ПФА
0,18-0,19 В медный электрод начинает переходить в пассивное состояние.

Поляризационные кривые для меди, предварительно обработанной в растворах изопропанола с различным содержанием полифторированного амина (ПФА), представлены на рисунке.

Как видно на рисунке, при нанесении на металлическую поверхность меди защитной пленки из растворов, содержащих ПФА, наблюдается значительное снижение максимума тока активного растворения меди на поляризационной кривой, что свидетельствует о замедлении скорости анодного растворения меди и торможении анодной реакции. Из приведенных данных следует, что величина предельного тока анодного растворения меди зависит от концентрации ПФА. Причем максимум анодной плотности тока, наблюдаемый на поляризационных кривых, уменьшается с повышением 
концентрации ПФА и достигает минимального значения для 3,32 \% раствора ингибирующей композиции на основе ПФА, что может свидетельствовать о повышении коррозионной стойкости ингибированной меди.

Однако только характер поляризационных кривых не позволяет однозначно судить о влиянии ингибитора на коррозионную стойкость меди в атмосферных условиях. Поэтому в дополнение к электрохимическим измерениям были проведены и натурные коррозионные испытания образцов медной катанки в камере солевого тумана Ascott 120 Plus.

Результаты электрохимических измерений согласуются с данными коррозионных испытаний. Коррозионные испытания показали, что очаги коррозии на медных образцах без ингибиру- ющей композиции, обработанных чистым изопропанолом, появлялись уже в первые же сутки выдержки образцов в камере. В то же время на образцах, обработанных в безводном растворе ингибирующей композиции на основе ПФА, коррозионные поражения появляются на 2-4 сутки в зависимости от концентрации ПФА. Из исследованных составов ингибирующих композиций лучшие результаты (до 4 суток) были достигнуты для 3,32 \% раствора ингибирующей композиции на основе ПФА

Таким образом, при использовании в ингибирующих композициях в качестве замедлителя коррозии меди полифторированных аминов можно повысить коррозионную стойкость медной катанки при ее транспортировке в экстремальных условиях.

1. Цыганкова Л. Е., Румянцев Ф. А. Влияние масляного покрытия и анионного состава электролита на ингибирование коррозии меди бензотриазолом в кислых средах // Коррозия: материалы, защцта. 2006;12:31-36.

2. Кузнецов Ю. И., Агафонкина М. О., Шихалиев Х. С., Андреева Н. П., Потапов А. Ю. Адсобция и пассивация меди триазолами в нейтральных водных растворах // Коррозия: материаль, защита. 2014;7:33-39. 